\title{
Cost Studies in Post-Secondary Education - Canada
}

\author{
Pierre-Paul Proulx*
}

\section{INTRODUCTORY COMMENTS}

A growing number of post-secondary education institutions and public bodies have recently terminated, are now pursuing, or are presently planning cost studies. This comes as no surprise in view of : a) the continued increase in real and money costs of education, b) the apparent absence of anticipated economies of scale, c) financial constraints which are prompting post-secondary education decision-makers to search for more economy in the processes of learning, research and community service, d) attempts to improve decision-making through new management information systems, and attempts to move forward Planning Programming Budgeting Systems (P.P.B.S.), changes which are prompting examination of the sources of costs, the proper accounting for costs incurred, and alternative costs to be envisaged, and e), changes occurring in the cational delivery systems.

This study will focus upon expenditure and cost analyses and neglect discussion of meaningful measures of the benefits of post-secondary education although comments are made on crude proxies for output. I hasten to add, however, that financing methods based upon cost analyses (especially historical costs) are in my view throughly inadequate, and that they can alone lead to distortions in the allocation of funds.

There will be no specific treatment of cost analysis of : trimester operations, co-operative and joint university-industry teaching and research programs, continuing education programs, medical programs, research, bilingualism, emerging institutions, etc. Similarly, no review is made of students' costs in terms of tuition fees, books, transportation, baby-sitting expenditures, foregone earnings, etc.

No attempt will be made to compare the quantitative results of the studies reviewed, because of differences in concepts, methods, and because of lacunae in the data upon which they are based.

* Pierre-Paul Proulx, Directeur du Centre de Recherches en Développement éco. nomique - Université de Montréal. The autbor wisbes: to thank Mark Segal for bis comments, 
Though it is possible to distinguish between individual, institutional, governmental and social costs, this study will concentrate mostly on concepts, methods and problems, which appeared in the following Canadian institutional cost studies :

1) The University of Calgary, Office of Institutional Research, A proposal for a Cost Study, 1969-70, March 1970;

2) A.U.C.C., An Exploratory Cost Analysis of Some Canadian Universities, Ottawa, 1970 ;

3) J.B. Macdonald, et al., The Federal Government and Reseach Grants in Canadian Universities, Science Council of Canada, Special Study no. 7 ;

4) Committee of Presidents of Universities of Ontario, Ring of Iron : A Study of Engineering Education in Ontario, December, 1970, and more particularly, I.W. Thompson and P.A. Lapp, A Method for Developing Unit Costs in Educational Programs, CPUO Report no. 70-3, December 1970 ;

5) M.D. Segal, The Political Economy of Resource Distribution in Quebec Universities, The Conference of Rectors and Principals of Quebec Universities, November 1970;

6) Systems Research Group, Cost and Benefit Study of Post-Secondary Education in the Province of Ontario ; School Year 1968-1969, April 1971.

A summary tabular comparison of these studies is attached (Appendix I). In addition, a summary of each study is available upon request from the Economic Council of Canada. These summaries are not a substitute for the original studies, and it is suggested that anyone concerned with the "nuts and bolts" of cost studies read them.

The paper does not present an examination of cost studies in the U.S., although comments on the state of the art in U.S. faculty workload studies will be made. Similarly, U.K. cost studies are excluded. ${ }^{1}$

One basic assumption underlying this study is that during the 1970's, the participants and the processes in education will have changed considerably. Cost analysis, if it is to be of assistance within this new context, will have to cope with the problems of program comparisons between manpower and education activities, and to some extent also with health and welfare programs. It is expected that the decision-making systems in the broad area of human resources policy formation will gradually come together, and thus prompt modifications in cost analysis. ${ }^{2}$ This payer will nevertheless focus upon studies which have been prepared in the current post-secondary education system.

\section{MAJOR PROBLEMS AND SUGGESTIONS FOR CHANGE AND FURTHER ANALYSIS}

This review of a few cost studies in Canada leads me to believe that even cost studies which would abstract from the cultural, social and emotional activities involved in post-secondary education are still faced with many problems.

The nature of the problems and the modifications called for are very much a function of the internal and external objectives of the cost analyses, e.g., whether they 
are used for internal budgeting purposes, or for external planning and forecasting purposes. If the purpose is the latter, it would seem that many extensions and modifications are called for. ${ }^{3}$

One of the major problems plaguing all of these attempts to determine the costs of instruction, research and other activities which are part and parcel of university life is that of joint inputs and joint outputs. I refer here more particularly to the difficulty of separating teaching from research. One can see the difficulties involved by recalling the A.U.C.C. and Macdonald study differences in dealing with graduate student thesis and research supervision. We know, for example, that graduate theses involve inputs of the student's time, and that the major output is a paper, or the conclusion of some experiment. The professor's contribution, both quantitative and qualitative, is acknowledged to be very difficult to measure. In addition, if the graduate student's paper or experiment forms part of the professor's research interests, we are faced with an intermediate input to the professor's research, hence a joint input problem. Perhaps a part of the answer lies in developing new research policies within universities, which policies might provide for a research professor status and the establishment of more clearly defined research centers as cost centers. However, here again the nature of many research problems calls for interdisciplinary approaches, and makes it difficult to impute research center costs to different budgetary units, should that be desired.

A closely related problem, and one very much affected by the teaching-research dichotomy is that of faculty and research workload analysis. We have seen that this is one of the major points of difficulty in the A.U.C.C. Study and that much controversy arose around the use of questionnaires and diary methods to help in the allocation of salary costs paid to university professors among research, teaching, community services, etc. It is here that the lack of knowledge of : a) the implications of audio-visual techniques and new pedagogic methods for faculty time inputs, b) the nature of consulting activities of professors (they may complement or simply be a substitute for formal teaching and research), c) the effects of class, faculty and university size on workloads, makes it presently difficult to arrive at a satisfactory distinction among teaching, reesarch and other functions in the university.

It is my impression that some future research efforts should also : a) attempt to weight the different components of teaching, research and other activities, ${ }^{4}$ b) distinguish lab from non-lab from field trip activities by level, by discipline, by institution, etc., c) utilize group results as against individual results, d) study the allocation of time in all pursuits, whether or not paid for by the university, etc. ${ }^{5}$

One thing which is quite striking is that very different questionnaires and diary approaches used to provide data on the faculty workloads yield strikingly similar results on faculty workloads. Nevertheless, thought should be given to the possibility of a multi-year sample collecting information professor by professor. 
With the exception of the S.R.C. study, and to some extent but in more restricted way the Segal study, most of the cost studies examined above paid no more than lipservice to the need to introduce opportunity costs into cost analysis, if at all. With the development of planning-programming-budgeting systems, the emphasis, it would seem, will go towards the explicit recognition and computation of costs in what is known to be the opportunity cost category. This suggests that much more use should be made of opportunity costs, using ex post data, though the subjectivist opportunity cost theories, as discussed by James $\mathrm{M}$. Buchanan, are appealing. ${ }^{6}$

Moving from accounting costs to opportunity costs implies being concerned with costs which do not appear in conventional accounting records and which do not entail actual dollar outlays. This entails estimating earnings that would have been realized if the actual assets were used otherwise. This involves much research which would take into consideration the fact that education is both consumption and investment and that education is an indirect social infrastructural investment that spills over into both private and social rates of return.

The S.R.G. study is a very interesting demonstration of the fact that the costs and benefits of post-secondary education, as determined by accounting costs, ${ }^{7}$ are very different from those determined by taking into account opportunity costs. More precisely, it would seem to me that cost studies in post-secondary education should cost all costs as much as possible, whether these be students' time or the costs incurred by students during the educational process for fees, transportation, baby-sittig and what have you; whether these be the interest costs in funds tied up in inventory, supplies, equipment and other non-capital assets of universities; whether these involve an imputation for municipal taxes (now levied in Ontario and Quebec) or an imputation for the value of services rendered by municipalities; whether these represent income tax collection foregone because of charitable contributions by individuals and corporations to universities; whether or not these involve evaluation of university buildings and equipment at market cost; whether or not these involve complex problems of imputation for the services of religious teachers who might not be paid according to lay professors' scales, etc.

In summary then, it seems to me that much more emphasis should be put into costing opportunity costs, for these rarely give results identical to accounting costs, and since it would seem that choices among alternative policies will more regularly make use of such a concept. ${ }^{8}$

Another significant problem area is that of determining meaningful ratios to apportion averbead costs of different kinds, if that is considered desirable. ${ }^{9}$ The A.U.C.C. study provides a good indication of the difficulties involved in proper apportionment of various types of administrative costs, computer costs, library costs, etc. to different programs. This involves two levels of apportionment problems, namely, the apportionment of overhead cost between budget units on one hand, and the translation from budget categories to whatever program categories are utilized in the cost analysis. ${ }^{10}$ 
Difficulties arise from lack of knowledge on objectives and on the nature of many of these costs, and from the poor accounting bases which exist in the universities. This problem is compounded because of the joint input and output problems involved in the university, as indicated above. Joint appointments between departments, interdisciplinary and inter-university research centers and teaching programs, etc. are reasons for developing inter-cost unit transactions accounting methods, in order properly to determine the total accounting and opportunity costs of training a student in different fields.

Another difficult area involving the same inter-cost unit accounting problem is that of pbysical plant accounting. Assuming that one would have adequate space inventories, with improvements over those being developed and quantified by the TaylorLieberfeld and Heldman group, one would still be faced with the difficulty of apportioning plant and equipment maintenance and annual depreciated capital costs centers. These problems are rendered more difficult because these costs are a function of: a) the utilization rates by different cost centers, b) the age of distribution of the capital stock, c) the location of the buildings and grounds, d) whether or not the equipment is rented or purchased, etc. The inadequate evaluation of plant assets in the public sector and in the universities, and the current practice of not using depreciation accounting except for those properties which are the investment of endowment funds adds to these problems. ${ }^{11}$ It is no significant extension of the opportunity cost concept to recognize that depreciation of plant and equipment in universities should be accepted, if only because some of the alternatives envisaged, such as health and welfare expenditures, or training in industry, make expenditures and costs in buildings and equipment of universities avoidable expenditures. It would seem that a proper accounting of costs of the alternative vying for public funds involved total accounting of all the costs involved, whether capital or operating.

It is also known that use of planning-programming-budgeting systems calls for some re-assessment of the distinction betwcen operating and capital costs, which is a very uneasy one in much of the literature.

Another problem which calls for further analysis is that of choosing the appropriate activity units in cost studies. We have seen costs reported by :

1) full-time equivalent student,

2) by staff contact hour,

3) by student contact hour,

4) by course,

5) by teaching unit,

6) by student by course hour,

7) by staff member,

8) by credit,

9) by places available, 
10) by course registrant,

11) by number of students who graduate,

12) by degree, etc.

Each of these activity units has its particular characteristics and each has its strengths and weaknesses in cost analysis. For example, the use of graduates may be preferable to the use of enrolments, which involves converting part-time students into full-time students on the basis of some arbitrary load, a problem which is very difficult at the graduate level. However, use of graduates involves knowledge of drop-out and failure rates, an area just recently being explored.

One might be tempted to suggest that the credit be used as the unit in cost analysis. However, if one reflects upon the nature of pedagogic changes occurring in universities, and the fact that formal contact hours within courses or within labs are only one of the components which might give rise to credit - other components being recognition of personal study by students -- one is prompted to reflect twice on that measure. In addition, courses of equal pedagogic (credit) value may be quite different in their cost implications.

At this stage in my analysis of the question, it would seem to me that a better measure would be to use staff contact hours, i.e. the time spent by staff instructing in different courses. This would seem to be of some interest, because doubling the number of students in the course does not necessarily double the instruction costs in that course. If it is found necessary, for pedagogic reasons or space reasons, to section the classes into groups, then the staff-contact hours might double, whereas the student-contact hours would remain the same. It would seem that a better basis for distributing costs would be a combination of both student and staff contact hours.

E.:.

It seems also that much thought should be given to costing on the basis of courses or activities within courses. The A.U.C.C. discussion of costs and cost differentials, among others, indicates the importance of the number and level of courses in the determination of costs. This cost unit is also singled out in the Segal and Committee of Presidents' studies, and it would seem that there is much to be said for retaining it as the basic unit for cost analysis. If one thinks of the need to simulate the cost of new pedagogic processes, it seems to me that the Segal study makes the point effectively that one will have to have very detailed cost units to make it possible to simulate very different pedagogic procedures. It might be preferable, therefore, to go into some kind of activity unit which is more detailed than a course. This would seem to be of a problem now with the use and prevalence of computers. However, the more microscopic the cost unit, the more macroscopic the imputation problems become. It may be, however, that variations in activities at such a disaggregated level will make it possible to consider many costs in the fixed category, and hence, of no concern to one making certain types of decisions. 
It would also seem that the course as a basic unit is indicated, in that it will become more and more prevalent to find students who are in different years of their educational experiment in any given course. Attempts to classify and determine the costs by years within level may therefore become more and more difficult as time goes on.

One of the problems with this suggestion, however, is of a planning and control nature. It is known that many universities are adverse to involvement of planning and governmental agencies in too much detail of university operations, and this for reasons which I consider perfectly valid. It might be argued that costing on a course basis would make for direct intervention into the course choices by the funding authority. A solution might be to estimate weighted average course costs by program field.

A closely related problem is that of choosing the budgetary unit for the cost study. This has usually been the department given the traditional structures of the university. Faculty costs have also been computed, and with new structures involving modules, it may be that it will be useful to compute costs for program definitions which are neither departments nor faculties, as would seem to be suggested by the increase in crossdepartmental registrations.

Another basic area for further research is that of trying to determine the nature of cost functions. It is prevalent to assume that cost functions are linear and homogeneous, and to stop the analysis with that assumption. It would seem to me that studies should be undertaken to determine whether there are economies of scale in program offerings of different universities. It is evident that as a university matures, its program offerings become more diversified; it becomes more graduate student intensive and hence, its costs per student increase. This, however, represents a mixture of static and dynamic factors, a question which I will come to in a few moments. Further studies should therefore be concerned with costs in emerging study and research programs of established universities, and in emerging universities. Such studies might be made on both cross-section and time series bases. Since there is a great tendency for cost analyses to be translated into weights in different formula financing methods, it would seem very important to determine the nature and shape of different cost functions within post-secondary education, so as not to either under-finance or over-finance different institutions, should the cost functions not be linear. Little is known about the costs of new programs utilizing new plant and equipment, and utilizing new pedagogic methods. Similarly, very little is known about idle capacity costs of such new programs.

All of the studies mentioned above, and more particularly those done by the A.U.C.C. and the Committee of Presidents brought forth the importance of program structures, pedagogic methods, class size and enrolments in determining university costs; but it should be kept in mind that these are cross-section studies, and that a proper explanation of changes of costs in higher education would probably be concerned much more with those factors underlying changes in university costs, and in particular, the remuneration and number of manpower units for some measure of output, for these are 
the bulk of university costs. In addition, if one is to think of time series analyses of university costs, one should attempt to segregate those costs which are more directly explained by variations in the number of students, from those whose variations are more closely tied to the number of staff, from those which vary with space: It might be of interest to attempt to classify costs into those which are exogenously determined, such as university professors' salaries, and those which are more affected by endogenous and internally controllable policy variables, such as staff-student ratios, changes in pedagogic procedures, and class sizes, etc.

In addition, any attempt to reconcile and explain cost differentials either at one points in time or over time should take into consideration the financing methods which bave been used to determine grants to universities, for it is well known that some of these financing methods have had as a purpose to expand the system, to increase the quality of the output of the system, and hence, to increase its costs. ${ }^{12}$

I suggest that it would be desirable to develop a cost index to deflate current costs of universities into real costs, and examine the changes in real costs as well as the changes in monetary costs.

If one is to attempt to understand cross-section cost differentials, or changes in such differentials, one would also have to take into consideration the bistorical development of the system, because it is well known that the structure of decision-making systems in different institutions is more or less decentralized, more or less in the process of changing, factors, which per se have much explanatory value in understanding differentials. Similarly, staff on hand in a university or college at any one point in time was hired at different points through time, times at which the labour market, hiring policies, promotion policies, etc. were not necessarily the same as they are presently. It would seem, therefore, that interpretation and correct analysis of changes in cost differentials in post-secondary education should be taken with the historical perspective also.

A basic requirement for useful cost analysis is significant improvement of data bases. Such an operation is underway in Quebec (SIGU) ${ }^{13}$ and in the Atlantic Provinces (MUSIC). This is by no means an easy operation, for it involves the determination of very precise definitions for different elements which enter into the data banks for staff, students, space, teaching and research programs, etc., and in addition, it involves some coordination of administrative procedures for the collection of data, etc.

Though there has been some improvement in the situation described by the A.U.C.C. Cost Study, it still remains a fact that inter-institutional comparisons of costs are very difficult, given differences in the way in which part-time students are defined, the way university professors are classified, etc. Without an effort to develop adequate data bases, cost analyses will remain very limited in their efficiency.

If the hypothesis made earlier, namely that the formal educational system will become more and more involved in joint teaching and research operations with industry 
and government is correct, it would seem to me that the data banks should be developed in such a way to encompass elements of information on details of activities involved in such areas.

\section{References}

1. See G. Wilson and P. Lewis, Cost Studies in Higher Education, Higher Education Research Unit, London School of Economics and Political Sciences, Reprint no. 34. Also published in Higher Education Review, Vol. 2, no. 2, Spring 1970, for a review of the subject in the U.K.

2. See Canadian Department of Manpower and Immigration and the U.S. Dept. of Labor, CostBenefit Analysis of Manpower Policies: Proceedings of a North-American Conference, May 14-15, 1969, Industrial Relations Centre, Queen's University, Kingston, and Conference on the Evaluation of the Impact of Manpower Programs, June 15.17, 1971, Ohio State University, for a discussion of these problems. The Economic Council of Canada's Eighth Annual Review presents an eloquent plea for such a vision of analysis in dealing with problems of human resources.

3. See chapters 3 and 4 of the Economic Council of Canada's Eighth Annual Review, for a discussion of the approaches involved.

4. For some purpose it may be preferable to make use of the weighted average number of students per staff contact hour rather than staff/student ratios.

5. See W.G. Bowen, "Teaching Schedules and Teaching Loads at Amherst, Columbia, Cornell, Dartmouth, Denison, Harvard, University of Michigan, Princeton, Stanford, Yale, and Vanderbilt", mimeo, 1970. This study computed the course load, supervisory load and an amal. gamation of both of these into teaching loads. Course load is the product of the number and mix of courses taught during a year, the average number of weekly course contact hours occasioned by each course, and the number of teaching weeks in a term. One's own undergraduate course was weighted 1 , teaching someone else's courses was weighted .67 , and teaching one's own graduate course was weighted 1.33. The supervisory load was calculated as the number of undergraduates supervised, plus 1.5 times the number of graduate students. To arrive at teaching loads, it was assumed that the factor $5 \mathrm{might}$ be used to relate the number of undergraduates supervised for one term, to teaching one course contact hour in one's own course for one term, i.e. to supervise the independent work of five undergraduates for one term was taken to be the equivalent of teaching one hour per week in one's own undergraduate course for one term.

See also the Interuniversity Council of Ohio, Faculty Load Study, January 1970 for a review of 92. studies of faculty workloads in higher education. The authors conclude that the use of a credit hour for evaluating an individual's contribution to the work of his university is less appropriate now than it was ten years ago, and that it was clearly inappropriate then. They indicate that in the last ten years, two separate paths of research have been taken in the United States on faculty workloads. The first attempts to develop incremental equivalents of non-classroom activities to the credit hour measure. The second approach summarizes the activities of all faculty members in terms of time spent in various types of work. They mention that typically, no attempt is made to relate these studies to the overall goals of the institution. They also mention the fact that such studies isolate predominantly instructional activities and neglect sponsored research and public service projects. In addition, they do not measure faculty effort in terms of knowledge, intensity of application of that knowledge, and time spent in that application. By study and by the presentation of expected profiles of effort in support of the processes of instruction, research and public service, they develop 


\section{SUMMARY TABULAR COMPARISON OF COST STUDIES *}

\begin{tabular}{|c|c|c|c|}
\hline Components & $\begin{array}{l}\text { The University of } \\
\text { Calgary Cost Study }\end{array}$ & $\begin{array}{l}\text { The A.U.C.C. } \\
\text { Cost Study }\end{array}$ & $\begin{array}{l}\text { John B.MacDonald \& al. } \\
\text { - Le gouvernement } \\
\text { fédéral et l'aide à la } \\
\text { recherche dans les } \\
\text { universités canadiennes }\end{array}$ \\
\hline $\begin{array}{l}\text { Date of data } \\
\text { collection } \\
\text { and/or } \\
\text { publication }\end{array}$ & $1969-70$ & $1966-67$ & Published in 1969 \\
\hline $\begin{array}{l}\text { Accounting } \\
\text { units }\end{array}$ & $\begin{array}{l}\text { University (Calgary) } \\
\text { Faculty (11) } \\
\text { Department (29) }\end{array}$ & $\begin{array}{l}\text { University (23) } \\
\text { Faculty (30) } \\
\text { Department (basic } \\
\text { cost center) }\end{array}$ & Federal Government \\
\hline $\begin{array}{l}\text { Program } \\
\text { categories }\end{array}$ & $\begin{array}{l}\text { Primary Programs } \\
\text { Instruction } \\
\text { ( } 5 \text { divisions) } \\
\text { Supervision Graduate } \\
\text { and Thesis } \\
\text { ( } 3 \text { divisions) } \\
\text { Research, } \\
\text { Creative Activity in Art } \\
\text { and Scholarship } \\
\text { Services to the Public } \\
\text { Secondary Programs } \\
\text { Administration } \\
\text { (3 divisions) } \\
\text { Services to the } \\
\text { Academic } \\
\text { Community } \\
\text { (4 divisions) } \\
\text { General Support } \\
\text { (2 divisions) }\end{array}$ & $\begin{array}{l}\text { Instruction } \\
\text { (6 divisions) } \\
\text { Student Research and } \\
\text { Thesis Work } \\
\text { (Master } \\
\text { and Doctoral) } \\
\text { Research } \\
\text { General Reading } \\
\text { and Study } \\
\text { Non-academic Student } \\
\text { Services } \\
\text { Administration (Univ., } \\
\text { Fac., Dept.) } \\
\text { Academic Organizations } \\
\text { Public and Community } \\
\text { Services }\end{array}$ & Research \\
\hline $\begin{array}{l}\text { Activity } \\
\text { units }\end{array}$ & $\begin{array}{l}\text { Winter-day students } \\
\text { Teaching unit } \\
\text { Staff member } \\
\text { Course registrant }\end{array}$ & $\begin{array}{l}\text { Full-time equivalent } \\
\text { student } \\
\text { Teaching unit } \\
\text { Course registrant }\end{array}$ & $\begin{array}{l}\text { Universities, } \\
\text { Industries, } \\
\text { Individuals }\end{array}$ \\
\hline $\begin{array}{l}\text { Workload } \\
\text { study }\end{array}$ & By questionnaire & By questionnaire & Visits and A.U.C.C. res \\
\hline $\begin{array}{l}\text { Simulation } \\
\text { capabilities }\end{array}$ & No & No & None \\
\hline Study's nature & Descriptive & Descriptive & Descriptive \\
\hline Costs' nature & Operating & Operating & Operating and capital \\
\hline
\end{tabular}




\begin{tabular}{|c|c|c|}
\hline $\begin{array}{l}\text { Committee of Presidents } \\
\text { of Universities of } \\
\text { Ontario, Study of } \\
\text { Engineering Education } \\
\text { in Ontario }\end{array}$ & $\begin{array}{l}\text { Conference of Rectors and } \\
\text { Principals of Quebec } \\
\text { Universities Cost Study }\end{array}$ & $\begin{array}{l}\text { Systems Research Group } \\
\text { Cost and Benefit Study of } \\
\text { Post-secondary Education }\end{array}$ \\
\hline $1969-70$ & 1968.69 & $1968-69$ \\
\hline $\begin{array}{l}\text { Universities of Ontario } \\
\text { Faculty (Engineering) } \\
\text { Department (12) }\end{array}$ & $\begin{array}{l}\text { Universities (2) } \\
\text { Faculty (2) } \\
\text { Department (2) }\end{array}$ & $\begin{array}{l}\text { Universities (15) } \\
\text { Community Colleges (21) } \\
\text { Teachers Colleges (16) } \\
\text { Nursing Schools (56) } \\
\text { Agricultural Colleges (4) }\end{array}$ \\
\hline $\begin{array}{l}\text { Teaching } \\
\text { Supervision and Research } \\
\text { Administrative Duties } \\
\text { Consulting } \\
\text { Professional and Public } \\
\text { Research Grants }\end{array}$ & $\begin{array}{l}\text { Instruction } \\
\text { Activities ( } 7 \text { cat.) } \\
\text { Time ( } 4 \text { cat.) } \\
\text { Students ( } 2 \text { cat.) } \\
\text { Staff ( } 3 \text { cat.) }\end{array}$ & $\begin{array}{l}\text { Institution ( } 3 \text { cat.) } \\
\text { Students ( } 2 \text { cat.) } \\
\text { Government ( } 4 \text { cat.) } \\
\text { Rest-of-the-Economy } \\
\text { Sponsored research (only } \\
\text { for simulation purposes } \\
\text { and through universities) }\end{array}$ \\
\hline $\begin{array}{l}\text { Full-time equivalent student } \\
\text { Staff contact hour } \\
\text { per student } \\
\text { Teaching unit } \\
\text { Number of students } \\
\text { who graduate }\end{array}$ & $\begin{array}{l}\text { Formal instructional unit } \\
\text { Students per contact hour } \\
\text { per teacher } \\
\text { Degree } \\
\text { Students }\end{array}$ & $\begin{array}{l}\text { Full-time equivalent } \\
\text { students } \\
\text { Program (77) } \\
\text { Degree (17) } \\
\text { Socio-economic strata } \\
\text { ( } 5 \text { classes) } \\
\text { Age ( } 5 \text { classes) }\end{array}$ \\
\hline $\begin{array}{l}\text { Questionnaire and } \\
\text { informal hearings }\end{array}$ & $\begin{array}{l}\text { Interviewing departmental } \\
\text { chairman }\end{array}$ & Nil \\
\hline Yes & Yes & Yes \\
\hline Descriptive and analytical & Analytical & Analytical \\
\hline Operating and capital & Wage units & $\begin{array}{l}\text { Direct (operating and } \\
\text { capital) and opportunity }\end{array}$ \\
\hline
\end{tabular}

* A summary of each study is available upon request from the Economic Council of Canada 
guidelines net of separately budgeted and funded research and public service. Assuming a minimum week of 40 hours per person on a full-time contract, they provide guidelines that "each state-assisted university expect at least $80 \%$ of the effort of its total faculty on an average, or at least 32 hours per week on a full-time equivalent basis, to be devoted to the instructional process of that university, except for those persons who have served separately budgeted and separately funded research of public service processes". They prefer individual service reports to questionnaires or diaries.

6. James M. Buchanan, Cost and Choice, Chicago, Markham Publishing Co., 1970.

7. It may be seen in Appendix II (available from the Economic Council of Canada) that use of Ontario formula weights limits the use which can be made of the actual dollar cost estimates presented in the S.R.G. Cost Study.

8. See R.W. Judy, "Costs : Theoretical and Methodological Issues", in Canadian Department of Manpower and Immigration and U.S. Department of Labor, Cost-Benefit Analysis of Manpower Policies, Proceedings of a North American Conference, May 14-15, 1969, pp. 20-21, for an interesting discussion of these differences.

9. For certain purposes which any economist interested in marginal costs could explain, the overhead costs are of little interest to decision-makers.

10. Of course, attempts might be made to apportion overhead costs directly to program categories.

11. American Council on Education, College and University Business Administration, revised edition, 1968, p. 148. Current practice is that if an institution is to provide for setting aside current fund revenues for the renewal, replacement and expansion of educational plant assets, the amount of such provisions should be shown in current fund categories. The orthodoxy, however, recognizes that these provisions for renewals and replacements which seem fairly analogous to depreciation, might be made for auxiliary enterprise plants, which in many instances are similar to commercial enterprises. In addition, depreciation accounting is accepted in endowment fund properties to "give reasonable protection to the principal of the funds so invested, and to reflect properly the net income from such investments". (p. 288).

12. See G. Wilson and P. Lewis, Cost Studies in Higher Education, op. cit,. for discussion along these lines.

13. Système informatique pour la gestion des universités, Comité de coordination du C.E.S.I.G.U., Ste-Foy, Québec, le 29 avril, 1971. 